Bahterasia: Jurnal Ilmiah Pendidikan Bahasa dan Sastra Indonesia

http://journal.umsu.ac.id/sju/index.php/bahterasia

\title{
MODEL STUDENT FACILITATOR AND EXPLAINING DALAM KEMAM-PUAN MENULIS ARGUMENTATIF
}

\author{
Aisiyah Aztry ${ }^{凶}$
}

Prodi Pendidikan Bahasa dan Sastra Indonesia, Fakultas Keguruan dan Ilmu Pendidikan, Universitas Muhammadiyah Sumatera Utara, Indonesia

\begin{tabular}{|c|c|}
\hline Info Artikel & Abstrak \\
\hline $\begin{array}{l}\text { Sejarah Artikel: } \\
\text { Diterima } \\
\text { Oktober } 2019 \\
\text { Disetujui } \\
\text { Desember } 2019 \\
\text { Dipublikasikan } \\
\text { Februari } 2020\end{array}$ & $\begin{array}{l}\text { Kemampuan menulis merupakan salah satu materi yang penting dalam pembelajaran di jenjang } \\
\text { universitas. Fenomena yang terjadi saat ini adalah masih terdapat kekurangan mahasiswa dalam } \\
\text { menulis. Oleh karena itu, diadakanlah penelitian ini untuk mengetahui penerapan model student } \\
\text { facilitator and explaining dalam upaya meningkatkan kemampuan menulis argumentatif mahasiswa } \\
\text { pendidikan bahasa dan sastra Indonesia FKIP UMSU. Dalam penelitian ini, digunakan metode Penelitian } \\
\text { tindakan kelas (PTK). Untuk memperoleh data, digunakan metode kualitatif dan kuantitatif. } \\
\text { Pemerolehan data merupakan hasil karangan mahasiswa yang berupa data kualitatif. Hasilnya dianalisis } \\
\text { dengan rubrik penilaian serta dinilai dalam bentuk kuantitatif. Hasil analisis data disajikan secara } \\
\text { deskriptif. Setelah penelitian, didapatkan hasil bahwa penerapan model student facilitator and } \\
\text { explaining mampu meningkatkan kemampuan menulis argumentatif mahasiswa pendidikan bahasa dan } \\
\text { sastra Indonesia FKIP UMSU. kemampuan menulis argumentatif mahasiswa mengalami peningkatan dari } \\
46,67 \% \text { menjadi } 76,6 \% \text { dan meningkat lagi menjadi } 80 \% \text {. }\end{array}$ \\
\hline & $\begin{array}{l}\text { Kata Kunci: model pembelajaran, kemampuan menulis, dan menulis argumentatif } \\
\text { Abstract }\end{array}$ \\
\hline & $\begin{array}{l}\text { The ability to write is one of the important material in learning at the university level. The current } \\
\text { phenomenon is that there is still a shortage of students in writing. Therefore, this study was held to } \\
\text { determine the application of the student facilitator and explaining model in an effort to improve the } \\
\text { argumentative writing skills of students of Indonesian language and literature education FKIP UMSU. In } \\
\text { this study, the Class Action Research (CAR) method was used. To obtain data, qualitative and } \\
\text { quantitative methods are used. Data acquisition is the result of student essays in the form of qualitative } \\
\text { data. The results are analyzed by the assessment rubric and assessed in quantitative form. The results of } \\
\text { data analysis are presented descriptively. After the research, it was found that the application of the } \\
\text { student facilitator and explaining model was able to improve the argumentative writing skills of the } \\
\text { students of Indonesian language and literature education FKIP UMSU. Student's argumentative writing } \\
\text { ability increased from } 46.67 \% \text { to } 76.6 \% \text { and increased again to } 80 \%\end{array}$ \\
\hline
\end{tabular}

Keywords: learning models, writing skills, and argumentative writing

(C) 2020 Universitas Muhammadiyah Sumatera Utara

\begin{tabular}{lr} 
Alamat korespondensi: & p-ISSN xxxx-xxxx \\
Kampus UMSU Jalan Kapten Muchtar Basri No 3, & e-ISSN xxxx-Xxxx \\
Medan-Sumatera Utara, 20238 & \\
e-mail: jurnalbahterasia@umsu.ac.id. & \\
\hline
\end{tabular}




\section{PENDAHULUAN}

Sejak dini, mahasiswa sudah diharapkan oleh banyak pihak untuk menjadi agent of change, atau agen perubahan dalam hal kebaikan. Pada laman http://unj.ac.id/pr3/?page_id=581 dengan tulisan yang berjudul Program Kreativitas Mahasiswa (PKM), dijelaskan bahwa Lulusan perguruan tinggi dituntut untuk memiliki academic knowledge, skill of thinking, management skill, dan communication skill. Kekurangan atas salah satu dari keempat keterampilan/kemahiran tersebut dapat menyebabkan berkurangnya mutu lulusan. Sinergisme akan tercermin melalui kemampuan lulusan dalam kecepatan menemukan solusi atas persoalan atau yang dihadapinya. Perilaku dan pemikiran yang ditunjukkan akan bersifat konstruktif realistis, artinya kreatif (unik dan bermanfaat) serta dapat diwujudkan. Kemampuan berpikir dan bertindak kreatif pada hakekatnya dapat dilakukan setiap manusia apalagi yang menikmati pendidikan tinggi. Kreativitas merupakan penjelmaan integratif dari tiga faktor utama dalam diri manusia, yaitu: pikiran, perasaan, dan keterampilan. Dalam faktor pikiran terdapat imajinasi, persepsi dan nalar. Faktor perasaan terdiri dari emosi, estetika dan harmonisasi. Sedangkan faktor keterampilan mengandung bakat, faal tubuh dan pengalaman. Dengan demikian, agar mahasiswa dapat mencapai level kreatif, ketiga faktor termaksud diupayakan agar optimal dalam sebuah kegiatan yang diberi nama Program Kreativitas Mahasiswa (PKM).

Dalam hal menyusun proposal PKM, mahasiswa harus memiliki bekal kemampuan menulis argumentatif. Menulis paragraf argumentasi sendiri sebenarnya tidak sulit, mahasiswa hanya perlu menggali kemampuan mereka dalam berpendapat atau beropini dan memperhatikan aspek penilaian dalam penulisan paragraf argumentasi. Jika itu diperhatikan dengan seksama, pencapaian mereka dalam menulis paragraf argumentasi dapat teratasi. Akan tetapi, yang sering terjadi di kelas adalah ketidakmampuan mahasiswa dalam menghubungkan kalimat yang satu dengan kalimat berikutnya, rasa takut yang tinggi dalam berpendapat di depan kelas, fakta yang disajikan tidak sesuai di lapangan, penulisan argumentasi yang lama, banyaknya memberikan argumen fiksi, penggalian ide yang buntu, simpulan yang tidak dibuat dan lain sebagainya.

Peneliti merasakan adanya kendala pada proses pembelajaran keterampilan menulis. Hal ini diketahui setelah berdiskusi dengan sesama dosen mata kuliah keterampilan menulis dan melihat hasil evaluasi mahasiswa. Satu di antara banyaknya cara untuk meningkatkan mutu proses pembelajaran bahasa, khususnya kemampuan menulis argumentatif perlu digunakan model student facilitator and explaining. Dengan model student facilitator and explaining, diyakini dapat meningkatkan antusias, motivasi, keaktifan, dan rasa senang pada pembelajar (mahasiswa), sehingga sangat tepat dalam materi bahasa.

Penelitian mengenai model student facilitator and explaining telah banyak dilakukan oleh para peneliti. Penelitian terhadap masalah ini bertujuan mencari jawaban atas pengaruh atau penerapan suatu model pembelajaran yang diterapkan. Meskipun demikian, para peneliti dan pendidik menyadari bahwa sampai sekarang belum ada model pembelajaran yang paling tepat untuk segala situasi dan kondisi. Oleh karena itu, upaya untuk mencoba menerapkan model pembelajaran perlu terus dilakukan dengan 
mempertimbangkan kondisi peserta didik, sifat materi bahan ajar, fasilitas, dan media yang tersedia.

Permasalahan model student facilitator and explaining selama ini telah banyak diteliti, antara lain dilakukan oleh Oktariani (2016) dan Muslim (2014). Dari hasil penelitian yang dilakukan Oktariani (2016) dengan judul Penerapan Student Facilitator and Explaining untuk Meningkatkan Aktivitas dan Hasil Belajar Siswa pada Mata Pelajaran Geografi Kelas X.E di SMA Negeri 1 Lawang Kidul Provinsi Sumatera Selatan Tahun Pelajaran 2015-2016 didapatkan bahwa (1) penerapan model pembelajaran kooperatif tipe Student Facilitator and Explaining dapat meningkatkan aktivitas belajar siswa (2) penerapan model pembelajaran Student Facilitator and Explaining dapat meningkatkan hasil belajara siswa.. Permasalahan penelitian Oktariani (2016) dengan permasalahan peneliti memiliki persamaan dan perbedaan. Persamaan kedua penelitian adalah menjadikan model pembelajaran Student Facilitator and Explaining sebagai model yang digunakan untuk meningkatkan hasil pembelajaran. Perbedaan, Oktariani dalam materi geografi sedangkan peneliti dalam hal kemampuan menulis.

Muslim (2014) melakukan penelitian dengan judul Pengaruh Penggunaan Student Facilitator and Explaining dalam Pembelajaran Kooperatif terhadap Kemampuan Pemecahan Masalah Matematik dan Kemampuan Berpikir Kritis Matematik Siswa SMK di Kota Tasikmalaya. Dari hasi penelitian ini disimpulkan bahwa kemampuan pemecahan masalah dan kemampuan berpikir kritis matematik pada kelompok siswa yang mengikuti pembelajaran kooperatif Student Facilitator and Explaining lebih baik daripada kelompok siswa yang mengikuti pembelajaran langsung, terdapat perbedaan kemampuan pemecahan masalah dan kemampuan berpikir kritis matematik pada kelompok atas, tengah, dan bawah yang mengikuti pembelajaran kooperatif Student Facilitator and Explaining, serta terdapat korelasi positif antara kemampuan pemecahan masalah dan kemampuan berpikir kritis matematik siswa yang mengikuti pembelajaran kooperatif Student Facilitator and Explaining. Permasalahan penelitian Muslim (2014) dengan penelitian ini memiliki persamaan dan perbedaan. Persamaan, meneliti mengenai Student Facilitator and Explaining pada pembelajaran. Perbedaan, Muslim menerapkan pada pembelajaran matematika sedangkan peneliti pada kemampuan menulis.

Dengan dua penelitian sebelumnya, dapat dipaparkan bahwa Student Facilitator and Explaining dapat meningkatkan antusias, motivasi, keaktifan, dan rasa senang pada pembelajar sehingga akhirnya dapat meningkatkan hasil belajar. Oleh karena itu, peneliti ingin menerapkan Student Facilitator and Explaining untuk meningkatkan kemampuan menulis argumentatif mahasiswa pendidikan bahasa dan sastra Indonesia FKIP UMSU.

Sementara itu, permasalahan mengenai kemampuan menulis argumentatif juga telah banyak diteliti, di antaranya oleh Santang (2017) dan Setiyaningsih (2008).

Peningkatan Kemampuan Menulis Teks Argumentatif yang Koheren pada Tulisan Mahasiswa STIBA Saraswati Denpasar merupakan hasil penelitian Santang (2017). Dalam penelitiannya, Santang (2017) mengungkapkan bahwa terdapat banyak kekurangankekurang dalam penulisan teks yang dilakukan oleh mahasiswa. Dalam penelitian ini, diterapkanlah teori konstruktivisme dalam meningkatkan kemampuan menulis argumentatif mahasiswa. Permasalahan penelitian Santang (2017) dengan penelitian 
peneliti memiliki persamaan dan perbedaan. Persamaan, meneliti mengenai pembelajaran kemampuan menulis argumentatif. Perbedaan, Santang menggunakan teori konstruktivisme sedangkan peneliti menggunakan model student facilitator and explaining.

Setiyaningsih (2008) melakukan penelitian dengan judul Peningkatan Kemampuan Menulis Argumentatif dan Keterampilan Berpikir Kritis Berbahasa Indonesia Mahasiswa melalui Model Pembelajaran berdasarkan Logika Toulmin. Menurut penelitian yang dilakukan Setiyaningsih, kemampuan menulis dan berpikir kritis di kalangan mahasiswa masih rendah. Oleh karena itu, Setiyaningsih melakukan upaya peningkatan dengan menerapkan model pembelajaran berdasarkan logika Toulmin. Permasalahan penelitian Setiyaningsih (2008) dengan penelitian peneliti memiliki persamaan dan perbedaan. Persamaan, meneliti mengenai upaya meningkatkan kemampuan menulis argumentatif. Perbedaan, Setiyaningsih menggunakan model pembelajaran berdasarkan logika Toulmin sedangkan peneliti menggunakan model student facilitator and explaining.

Berdasarkan dua penelitian yang berkaitan dengan kemampuan menulis argumentatif, dapat dirumuskan bahwa perlu adanya variasi dan perbaikan dari waktu ke waktu dalam menggunakan metode, model, dan media pembelajaran untuk memberikan pengaruh yang lebih baik terhadap kemampuan menulis argumentatif di kalangan mahasiswa. Dua penelitian sebelumnya dan penelitian peneliti menjadikan mahasiswa sebagai subjek penelitian.

Model pembelajaran student facilitator and explaining merupakan salah satu dari tipe model pembelajaran kooperatif. Model ini memiliki kelebihan, yaitu pembelajar diajak untuk dapat menjelaskan kepada pembelajar lainnya atau menjadi narasumber terhadap temannya di kelas. Langkah-langkah model pembelajaran student facilitator and explaining menurut Istarani (2011: 97) sebagai berikut: 1) Staf pendidik (dosen) menyam-paikan kompetensi yang ingin dicapai. 2) Staf pendidik mendemonstrasikan/menyajikan garis-garis besar materi pembelajaran. 3) Memberikan kesempatan kepada mahasiswa untuk menjelaskan kepada mahasiswa lain tentang pokok materi. Hal ini dilakukan secara bergilir dari satu mahasiswa ke mahasiswa lain. 4) Staf pendidik menyimpulkan ide/pendapat dari mahasiswa. 5) Staf pendidik menerangkan semua materi yang disajikan saat itu. 6) Evaluasi. 7) Refleksi. 8) Penutup.

\section{METODE PENELITIAN}

Penelitian ini dilakukan Lokasi penelitian dilakukan di Program Studi Pendidikan Bahasa dan Sastra Indonesia FKIP UMSU, Jl. Mukhtar Basri No.3 Medan.Waktu penelitian dilakukan pada Tahun Akademik 2017-2018. Metode yang digunakan adalah penelitian tindakan kelas (PTK). Melalui PTK ini, diharapkan permasalahan yang dipaparkan sebelumnya dapat diselesaikan dengan baik. Ciri penelitian tindakan kelas adalah dilakukan dengan bersiklus, yang terdiri dari empat tahapan, yaitu : perencanaan, pelaksanaan, pengamatan, dan refleksi. Penelitian kali ini direncanakan akan dilaksanakan minimal dua siklus dan tiap-tiap siklus terdiri dari dua pertemuan. Teknik pengumpulan data atau instrumen yang digunakan dalam penelitian berupa tes, yaitu tes esai. 


\section{HASIL PENELITIAN DAN PEMBAHASAN}

\section{Hasil Penelitian}

\section{Deskripsi Kondisi Awal}

Sebelum penelitian tindakan kelas ini dilaksanakan, peneliti melaksanakan observasi pengumpulan data dari kondisi awal kelas yang akan diberi tindakan. Pengetahuan awal ini perlu diketahui agar diberi tindakan sesuai dengan yang dibutuhkan oleh kelas dan peneliti. Penilaian terhadap kemampuan menulis argumentatif dilaksanakan pada tes awal, tes akhir siklus I, dan tes siklus II. Dari hasil tiap-tiap tes tersebut dapat dilihat seberapa besar peningkatan yang diperoleh mahasiswa.

Pada kondisi awal, kemampuan menulis argumentatif mahasiswa masih rendah. Hal ini dibuktikan dengan nilai rata-rata mereka sebesar 68,03. Data selengkapnya dapat dilihat pada tabel 1 sebagai berikut.

Tabel 1

Distribusi Frekuensi Nilai Kemampuan Menulis Argumentatif pada Kondisi Awal

\begin{tabular}{cccccc}
\hline No & Interval Nilai & fi & Xi & fi.xi & Presentase (\%) \\
1. & $58-61$ & 7 & 59,5 & 416,5 & 23,34 \\
2. & $62-65$ & 5 & 63,5 & 317,5 & 16,67 \\
3. & $66-69$ & 4 & 67,5 & 270 & 13,33 \\
4. & $70-73$ & 10 & 71,5 & 715 & 33,33 \\
5. & $74-77$ & 4 & 75,5 & 302 & 13,33 \\
\hline & 30 & & 2041 & 100,00 \\
\hline
\end{tabular}

Berdasarkan tabel 1 , mahasiswa yang sudah mencapai nilai $\geq 70$ ada 14 mahasiswa atau 46,67\%, sedangkan 16 mahasiswa atau 53,33\% lainnya mendapat nilai $<70$. Nilai rata-rata kelas pada kondisi awal adalah 68,03 dengan nilai tertinggi 76 dan nilai terendahnya 58.

\section{Deskripsi Siklus I}

Siklus ini dilaksanakan pada pertemuan ke 2 (dua) sampai dengan pertemuan ke 7 (tujuh) sehingga peneliti menyusun perencanaan pengajaran untuk enam pertemuan pada satu siklus.

Tahapan ini dimulai dari perencanaan. Pada tahap perencanaan ini peneliti melakukan beberapa aktivitas, yaitu :

1) Peneliti melakukan analisis kurikulum untuk mengetahui kompetensi dasar yang akan disampaikan kepada mahasiswa dengan penerapan model pembelajaran student facilitator and explaining.

2) Membuat Rencana Pembelajaran Semester (RPS).

3) Menganalisis yang bertujuan untuk mengetahui tersedianya alat dan bahan pelajaran.

4) Membuat lembar observasi.

5) Menyiapkan evaluasi hasil belajar. 
Tahapan selanjutnya adalah tindakan. Pemberian tindakan I dengan melaksanakan pembelajaran dan peneliti sebagai dosen di kelas dilaksanakan dengan menggunakan model pembelajaran student facilitator and explaining.

Tabel 2

Skor Mentah Kemampuan Mengidentifikasi Jenis-jenis Puisi pada Kelas Kontrol

\begin{tabular}{|c|c|c|c|c|c|}
\hline No & Interval Nilai & $\mathrm{Fi}$ & $\mathrm{Xi}$ & fi.xi & Presentase (\%) \\
\hline 1. & 58-61 & 2 & 59,5 & 119 & 5,67 \\
\hline 2. & $62-65$ & 2 & 63,5 & 127 & 5,67 \\
\hline 3. & $66-69$ & 3 & 67,5 & 202,5 & 10 \\
\hline 4. & $70-73$ & 9 & 71,5 & 643,5 & 30 \\
\hline 5. & $74-77$ & 7 & 75,5 & 528,5 & 23,33 \\
\hline 6. & $78-81$ & 5 & 79,5 & 397,5 & 16,67 \\
\hline 7. & $82-85$ & 2 & 83,5 & 167 & 6,67 \\
\hline \multirow{2}{*}{\multicolumn{2}{|c|}{ Jumlah }} & \multirow[t]{2}{*}{30} & & 2185 & 100,00 \\
\hline & & & Rata- rata & 72,83 & \\
\hline
\end{tabular}

Pada siklus I, kemampuan menulis mahasiswa sudah meningkat. Mahasiswa yang sudah mencapai nilai $\geq 70$ sebanyak 23 orang atau $76,67 \%$, sedangkan 7 orang atau $23,33 \%$ lainnya mendapat nilai $<70$. Nilai rata-rata kelas 72,83 dengan nilai tertinggi adalah 82,5 dan nilai terendahnya 60. Namun, masih ada beberapa mahasiswa yang merasa kesulitan dalam menganalisis permasalahan sehingga nilai rata-rata kelas belum mencapai indikator kinerja $80 \%$ dan dilanjutkan pada siklus II.

\section{Deskripsi Siklus II}

Berdasarkan hasil refleksi pada siklus I, persiapan yang dilakukan sebelum mengaplikasikan model pembelajaran student facilitator and explaining dalam kegiatan pengajaran menulis di kelas adalah sebagai berikut: a) Skenario pembelajaran dibuat untuk digunakan pada siklus II dan mempersiapkan teknik yang lebih sesuai dengan kondisi siswa, alat dan bahan mengajar, b) Mempersiapkan materi ajar dan topik-topik yang lebih menarik dan kekinian untuk melatih kemampuan menulis mahasiswa, dan c) Mempersiapkan tes akhir untuk diberikan kepada mahasiswa di akhir siklus.

Pemberian tindakan II dengan melaksanakan pembelajaran dan peneliti sebagai dosen di kelas. Pembelajaran yang dilaksanakan dengan menggunakan model pembelajaran student facilitator and explaining pada siklus II. Pada siklus II, mahasiswa mengalami banyak peningkatan. Siswa lebih aktif dan percaya diri dalam menyampaikan ide masing-masing. Persentase ketuntasan klasikalnya meningkat menjadi 80\%. Distribusi frekuensi nilai kemampuan menulis siklus II dapat dilihat pada tabel 3 di bawah ini.

Tabel 3

Distribusi Frekuensi Nilai Kemampuan Menulis Argumentatif pada Siklus II

\begin{tabular}{cccccc}
\hline No & Interval Nilai & Fi & Xi & Fi.xi & Presentase (\%) \\
\hline 1. & $58-63$ & 1 & 60.5 & 60,5 & 3,33 \\
2. & $64-69$ & 4 & 66,5 & 266 & 13,33 \\
3. & $70-75$ & 2 & 72,5 & 145 & 6,67 \\
4. & $76-81$ & 2 & 78,5 & 157 & 23,33 \\
5. & $82-87$ & 9 & 84.5 & 760,5 & 20 \\
6. & $88-93$ & 7 & 90,5 & 633,5 & 20 \\
7. & $94-99$ & 5 & 96,5 & 482,5 & 13,33 \\
\hline \multicolumn{7}{r}{} & Jumlah & 30 & & 2505 & 100,00 \\
\hline
\end{tabular}


Berdasarkan tabel 3 di atas, diketahui bahwa mahasiswa yang mencapai nilai $\geq 70$ bertambah menjadi 24 orang atau $80 \%$, sedangkan 6 orang atau $20 \%$ lainnya mendapat nilai < 70. Nilai rata-rata kelas menjadi 83,5 dengan nilai tertinggi 97,5 dan nilai terendahnya 62,5. Dari hasil tersebut dapat diketahui bahwa upaya untuk meningkatkan kemampuan menulis dengan menerapkan model pembelajaran student facilitator and explaining berhasil karena sudah mencapai target indikator kinerja, yaitu 80\%. Oleh karena itu, penelitian dapat dihentikan.

Dari hasil analisis data di atas, dapat dilihat bahwa tes tindakan II telah mencapai syarat ketuntasan belajar. Kegiatan situasi belajar mengajar yang dapat dilihat pada lembar observasi kegiatan mahasiswa, yaitu pembelajaran yang terjadi di dalam kelas tergolong baik.

\section{Pembahasan Hasil Temuan Penelitian}

Pada kondisi awal, sebelum dosen menerapkan model pembelajaran student facilitator and explaining, mahasiswa yang sudah mencapai nilai $\geq 70$ ada 14 mahasiswa atau 46,67\%, sedangkan 16 mahasiswa atau 53,33\% lainnya mendapat nilai $<70$. Nilai rata-rata kelas pada kondisi awal adalah 68,03 dengan nilai tertinggi 76 dan nilai terendahnya 58. Pada pelaksanaan siklus I, dosen sudah menerapkan model pembelajaran student facilitator and explaining, terjadi peningkatan nilai rata-rata kelas, mahasiswa yang sudah mencapai nilai $\geq 70$ sebanyak 23 orang atau 76,67\%, sedangkan 7 orang atau $23,33 \%$ lainnya mendapat nilai $<70$. Nilai rata-rata kelas 72,83 dengan nilai tertinggi adalah 82,5 dan nilai terendahnya 60. Pembelajaran berjalan dengan lancar, tetapi persentase ketuntasan belum mencapai target indikator kinerja yang ditetapkan, yaitu 80\%. Hasil pengamatan dan diskusi bersama dosen serta teman sejawat selama siklus dilaksanakan, menyimpulkan bahwa penyebab ketidaktuntasan mahasiswa dikarenakan ketidakmampuan mahasiswa dalam menghubungkan kalimat yang satu dengan kalimat berikutnya, rasa takut yang tinggi dalam berpendapat di depan kelas, fakta yang disajikan tidak sesuai di lapangan, penulisan argumentasi yang lama, banyaknya memberikan argumen fiksi, penggalian ide yang buntu, simpulan yang tidak dibuat dan lain sebagainya.

Oleh karena itu, peneliti bersama dosen dan teman sejawat melanjutkan tindakan ke siklus II. Pada siklus II, perbaikan kinerja dosen dan pemberian motivasi kepada mahasiswa untuk lebih aktif dalam pembelajaran mengalami peningkatan. Kinerja dosen semakin baik dan mahasiswa menjadi tampak bersemangat dan lebih aktif. Nilai rata-rata kelas pada siklus ini menjadi 83,5 dan persentase ketuntasan klasikal meningkat menjadi 80\%. Hasil tersebut menunjukkan hasil yang diperoleh sudah mencapai indikator kinerja yang ditetapkan sehingga peningkatan ini dikatakan berhasil. Model ini menyajikan cara belajar yang tidak membosankan yang menekankan pada tiga tahap penting untuk mencapai keberhasilan dalam hasil belajar mahasiswa.

Data peningkatan kemampuan menulis pada kondisi awal, siklus I, dan siklus II dapat dilihat pada tabel 4 berikut ini.

Tabel 4

Data peningkatan kemampuan menulis argumentatif sebelum dan sesudah tindakan

\begin{tabular}{cccc}
\hline Tindakan & Nilai rata-rata & Jumlah mahasiswa tuntas & Persentase ketuntasan \\
\hline Kondisi Awal & 68,03 & 16 & $46,67 \%$ \\
Siklus 1 & 72,83 & 23 & $76,67 \%$ \\
\hline
\end{tabular}


Adapaun hambatan yang terjadi dalam penerapan model pembelajaran student facilitator and explaining pada setiap pertemuan di setiap siklus hampir sama, diantaranya ketidakmampuan mahasiswa dalam menghubungkan kalimat yang satu dengan kalimat berikutnya, rasa takut yang tinggi dalam berpendapat di depan kelas, fakta yang disajikan tidak sesuai di lapangan, penulisan argumentasi yang lama, banyaknya memberikan argumen fiksi, penggalian ide yang buntu, simpulan yang tidak dibuat dan lain sebagainya. Pada siklus II ini, persentase peningkatan kemampuan menulis argumentatif mencapai $80 \%$.

\section{SIMPULAN}

Penerapan model pembelajaran student facilitator and explaining mampu meningkatkan kemampuan menulis argumentatif mahasiswa Pendidikan Bahasa dan Sastra Indonesia FKIP UMSU. Kemampuan menulis argumentatif mahasiswa mengalami peningkatan dari $46,67 \%$ menjadi $76,6 \%$ dan meningkat lagi menjadi $80 \%$..

\section{DAFTAR PUSTAKA}

Arikunto, Suharsimi dan Suharjono, Supriadi . 2008. Penelitian Tindakan Kelas. Jakarta: Bumi Aksara.

Burns, A. 2010. Doing Action Research in English Language Teaching. New York: Routledge.

Istarani. 2011. Metode Pembelajaran Inovatif. Medan: Media Persada.

Keraf, Gorys. 2005. Argumentasi dan Narasi. Jakarta: PT. Gramedia.

Muslim, Siska Rayne. 2014. "Pengaruh Penggunaan Student Facilitator and Explaining dalam Pembelajaran Kooperatif terhadap Kemampuan Pemecahan Masalah Matematik dan Kemampuan Berpikir Kritis Matematik Siswa SMK di Kota Tasikmalaya". Jurnal Pendidikan dan Keguruan, Volume 1, Nomor 1, Hal 1-9.

Oktariani, Elisa. 2016. "Penerapan Student Facilitator and Explaining untuk Meningkatkan Aktivitas dan Hasil Belajar Siswa pada Mata Pelajaran Geografi Kelas X.E di SMA Negeri 1 Lawang Kidul Provinsi Sumatera Selatan Tahun Pelajaran 2015-2016". Skripsi. Universitas Lampung.

Santang. 2017. "Peningkatan Kemampuan Menulis Teks Argumentatif yang Koheren pada Tulisan Mahasiswa STIBA Saraswati Denpasar". Jurnal Linguistika, Volume 24, Nomor 46, Hal.107-116, ISSN 0854-9613.

Setiyaningsih, Yuliana. 2008. "Peningkatan Kemampuan Menulis Argumentatif dan Keterampilan Berpikir Kritis Berbahasa Indonesia Mahasiswa melalui Model Pembelajaran berdasarkan Logika Toulmin". Jurnal Educationist, Volume II Nomor 2, Hal.98-111, ISSN 1907-8838 